\title{
MINORITY AND DISSENTING SHAREHOLDERS' RIGHTS IN FUNDAMENTAL CHANGES
}

\author{
NORMAa D. LaTrin*
}

One necessarily starts with the principle that the corporate charter constitutes a contract not only between the corporation and its owners and between the owners themselves, but also between the corporation and the state-a principle which derives: from the important Dartmouth College case ${ }^{1}$ and tha early cases which followed it. An element that must be read into this contract, therefore, is comprised of the pertinent constitutional and statutory provisions, one kind of which, that governing. the power to alter, amend, or repeal corporate charters, created some interesting, albeit difficult, problems.

Prior to the inception of such provisions, fundamental corporate change could. be effected only by the state through the exercise of its police power or, in some cases, with the unanimous consent of the shareholders or members. Since the interests of the state were thus protected in a reasonably adequate manner, the explicit reservation of the power to alter, amend, or repeal corporate charters was widely held to extend the state's authority beyond the area of policy and into that of the shareholders' contract. Most of the cases-and the better ones, too-accordingly, held that this authority was sufficiently extensive to compel changes in the shareholders' contract, either directly by statute or through a prescribed vote of shareholders authorized by statute. In either event, however, the important point ultimately established was that no longer did the federal constitutional injunction: against the impairment of the obligation of contracts protect against changes made in accordance with the statutory procedure, provided the corporation either had been born after this power to alter, amend, or repeal had become effective or had accepted the new power as if incorporated into its earlier charter. There was not universaI agreement, however, on such broad interpretations.

Although fundamental changes of the shareholders' contract were thus legalized, some courts took the cautious view that the statute must spell out in specific language the changes which might be made; others, on the other hand, permitted reliance upon broad, undefined language-for example, the authorization of changes which. might have originally been included in the articles or certificate of incorporation.

*A.B. 1918, Colby College; J.D. I924, University of Michigan; S.J.D. 1931, Harvard University. Member of the Michigan bar; Professor of Law, The Ohio State University. Author, Cases AND" Materials on Sales (I947); co-author [with Henry W. Ballantine and Richard W. Jennings], Cases and Materials on Corporations (2d ed. r953). Contributor to legal periodicals. The author reserves. the right to use all or any part of this article in a text on corporations which is to be published at an early date.

${ }^{1}$ Trustees of Dartmouth College v. Woodward, ${ }_{7}$ U.S. (4 Wheat.) 518 (1819). 
Another principle, moreover, prohibited the taking of property without due process of law, and this, too, was evoked by some courts to discourage major corporate changes. But it should be noted that as far as the shareholders' contract was concerned, each provision looked very much like other contractual provisions, and not like vested property rights of the sort that the due process clause was intended to protect-that is, unless a court were to go the whole way and call all contractual provisions vested property rights, a thing none has been willing to do. Furthermore, many constitutional rights may be waived, and, if necessary, it could be said that such a waiver was exercised when the shareholder took his shares subsequent to the insertion in constitutions and statutes of the reservation to alter, amend, or repeal corporate charters.

The course of case law in this area has, in short, been arduous and long, and the conclusions reached have not all been harmonious, but their soundness is now no longer doubted. ${ }^{2}$

This article will discuss generally the major corporate changes which have been analyzed as usurpations of the shareholders' contractual rights; more particularly, it will focus on the compromise solution afforded by appraisal remedies when such changes are made.

Where there is a fundamental change made in the purposes for which the corporation was organized; or where there is a sale of a substantial part or all of the assets of a corporation out of the ordinary and regular course of business; or where there is a merger or consolidation, or a change in the share contract, or a dissolution of a prosperous corporation, shareholder rights are altered or obliterated in the process. Prior to the enactment of enabling statutes, the common law, in general, did not permit such basic corporate changes without the unanimous consent of the owners and, in case of a merger or consolidation, without the consent of the state. ${ }^{3}$ In this respect, the owners of the corporation were treated approximately as if they were partners, where the rule contemplates unanimity of action in any activity exceeding that set out in the partnership agreement.

This rule of unanimous action had some validity in the small, closely-held, corporation which, in many respects, functioned informally, as if it were a partnership, with its owners, as "employees," devoting their full time to the business, as partners quite customarily do. When the closely-held corporation became less closely held, however, so that there were owners who did not actively participate in carrying

${ }^{2}$ For a more extensive treatment of this difficult subject, see Lattin, A Primer on Fundamental Corporate Changes, I Western Res. L. Rev. 3 (I949).

${ }^{3}$ Professor Warren was emphatically of the opposite opinion, writing: "The general rule at common law is that (apart from some agreement of the members to the contrary) all corporate powers arc vested in the members of the corporation, and that a decision of the majority as to the exercise of such power binds the minority." Warren, Voluntary Transfers of Corporate Undertakings, 30 Harv. L. Rev. 335, 346 (Igr7). The traditional view, however, is contrariwise. But Professor Dodd did express the view that "even at common law it is by no means clear that the majority cannot sell all the asscts of a corporation without regard to its financial condition, provided that the sale is made to a stranger and for cash." Dodd, Dissenting Stockholders and Amendments to Corporate Charters, 75 U. PA. L. REv. $585 ;$ id. at 723,734 (I927). 
on the business and who were more interested in productive investments than in keeping the family corporation within its previously established bounds, there arose the need for a more democratic approach. This involved choices which depended upon policies, which, in turn, depended upon local tradition, which, in many states, reflected the type of corporation carrying on business within its borders-either small and closely-held or larger and publicly-held. Also, and quite naturally, there was the urge, here and there, for revenue purposes, to induce businesses operating outside the state to incorporate under the local statute, as well as to encourage businesses within the state to use the local statute rather than foreign ones for corporate creation. And statutes which are "liberal" will accomplish such purposes-particularly so when they permit corporate change readily and without too great a threat of obstruction from minority owners.

In the case of a sale or exchange of assets of a corporation, particularly a successful one, there first had to be decided such questions as whether all sales of all or a substantial part of the corporate assets should require shareholder authorization, or whether certain distinctions should be drawn: Should a sale in ordinary course of business require more than the board's approval? Should one for a consideration other than cash-shares of stock in another or the purchasing corporation, for example-require the approval of the owners? Should a mortgage, deed of trust, or pledge of all the assets for a loan or to secure an indebtedness already assumed require more than board action? Should a sale of the assets of a going concern be treated differently from one of a failing corporation? In what cases, if any, should a dissenting shareholder be given a right to demand payment for his shares? Should the board, without the approval of the owners, be able to abandon a sale properly authorized-and, if so, upon what conditions? As might be expected, a variety of answers has been given by the statutes, but if generalizations are possible, it may be said that a sale in ordinary course of business needs no more than board action nor, by and large, does a mortgage, deed of trust, or pledge of corporate assets to secure a debt; that a sale or exchange of assets out of the ordinary and regular course of business requires shareholder action, and occasionally board action as well; and that a sale of the assets of a going concern is frequently distinguished from that of one on the brink of insolvency, the latter requiring board action alone.

Somewhat similar questions must be asked in case of a material change in the corporate purposes or in the share contract of a class of shares. Determinations must be made as to who may vote upon specific provisions; what proportionate vote is needed to carry a resolution; what preliminary steps are necessary before submitting a resolution to the shareholders; whether the shareholders, in their meeting, may significantly change the resolution submitted to them by their board; and whether the board may, without shareholder consent, abandon an authorized change. In these changes, there may also be possible dangers to the owners. Some may be willing to assume the risk; others, however, may prefer to sell out and invest in other ventures. 
And so it is, too, in the case of mergers and consolidations. The shock here is great enough to warrant the conclusion that no shareholder should be required to surrender his shares for new ones in either a corporation into which his has merged or a newly organized one into which his and other companies have consolidated; nor should he be required to retain his shares in his own corporation when other companies have merged into it and new shares have been issued to others in the process. But there are still problems as to who should be permitted to vote in the matterthat is, holders of shares of whatever kind, holders of only those which have voting rights, or holders of those which have only a right to vote on the specific resolution to merge or consolidate, if such there be.

In the case of an authorization to dissolve a prosperous corporation, who may vote and what proportion may carry the resolution are, again, matters of policy. If it is to be an honest dissolution for the purpose of going out of business, and not simply to freeze out a minority group, there would seem to be no basis upon which to argue a further policy of appraisal for those dissenting. Dissolution means an end to the corporation, and, after the payment of debts and expenses, the remaining assets are distributed in accordance with the shareholders' contract and, if there are no special contracts giving preferences, then pro rata, each share being equal to every other one.

Thus, while owners should be permitted to participate in making a decision involving a material or fundamental change, choices must be made as to which owners, if less than all, should have this right; how it is to be exercised-that is, through what formalities; and how large the vote or consent must be to authorize the particular change. Policy factors will dictate whether dissenting shareholders shall have the further right of demanding payment of the value of their shares, thus giving them the right of retreat from the disadvantage or risk they feel the particular corporate alteration involves. A delicate balancing of the interests of majority and minority owners is necessary, for the majority owners should not be chained to what they believe to be unsound business judgment; yet, neither should the minority owners be bound to remain shareholders when they have similar misgivings. And whether a dissenting shareholder should be able to contest more than the validity of the vote through which the change purported to be authorized is also a question of policy which should be decided by balancing, on the one hand, the possible dangers of unlimited freedom to legislate fundamental changes through majority vote and, on the other, the power of a minority to prevent prompt action by threats of suits to enjoin changes claimed to be unauthorized or not effectuated in the prescribed manner.

An examination of the statutes discloses some interesting details from which some conclusions may be drawn. All states require shareholder approval of mergers and consolidations; and the forty-six states and the District of Columbia having appraisal provisions sanction the corporate purchase of dissenting owners' shares, at the owners' 
option. ${ }^{4}$ Ignoring the exceptions in which a shareholder vote is not required, fortyfour states and the District of Columbia specifically permit the sale, lease, or exchange of all or a substantial part of a corporation's assets, when authorized by the shareholders; ${ }^{5}$ but in fifteen of these, there is no appraisal provision which permits a dissenter to withdraw and be paid off. ${ }^{6}$ This is somewhat surprising, as many of these jurisdictions specifically permit an exchange or barter of assets and the payment in shares of the purchasing or some other corporation. The fact that twenty-nine states do afford appraisal rights under such circumstances, however, indicates that the policy of protecting the dissenter in this way is rather well-intrenched.

Although shareholder approval is needed where substantial changes are made in the purpose clause of the articles or certificate of incorporation, there are very few statutes which permit the shareholder the election of withdrawing by requiring the corporation to purchase his shares. ${ }^{7}$ This may reasonably be attributed to the not too wholesome custom of drafting the purpose clause broadly enough to include practically any business which the board determines will be profitable to the owners. Hence, shareholders are led to expect change. And there seems to be no doubt that the hunt for diversification of products, thought to be so necessary to business success today, has also had its influence.

While the shareholder is usually given the right to vote upon material changes in his contract that adversely affect or may affect his class of shares, even though he may not be permitted to vote in other situations, there are surprisingly few statutes that give him the additional right of withdrawing, if he so elects, by requiring the corporation to purchase his shares. ${ }^{8}$ The weighty policy considerations that warrant appraisal in the case of a merger or consolidation and in the case of a sale, lease, or exchange of all or substantially all of the corporate assets that are lacking in the case of a material change in the shareholder's contract, however, are not im-

"There are no specific statutory provisions in Utah and West Virginia.

- There are no specific statutory provisions in Arizona, Iowa, Mississippi, and Wyoming.

- Appraisal provisions to a full or lesser extent in the case of a sale, lease, or exchange of assets exist in Connecticut, Idaho, Illinois, Indiana, Kentucky, Louisiana, Maine, Maryland, Massachusetts, Michigan, Missouri, Montana, New Hampshire, New Jersey, New Mexico, New York, North Carolina, North Dakota, Ohio, Oklahoma, Oregon, Rhode Island, South Carolina, Tennessee, Texas, Vermont, Virginia, Washington, and Wisconsin. Model Business Corporatron Act $\$ 74$ also permits appraisal in the case of sales in other than the ordinary course of business.

${ }^{7}$ These statutes permit appraisal in such cases: LA. Rev. Star. $\$ 12: 52$ (r950); Mass. Gen. Laws c. 156, $\$ 46$ (1932), as amended by Mass. Laws I943, c. 38, $\$ 2$; Minn. Stat. $\$ 30$ I.40 (I953); Ohio REv. Code ANN. $\$$ ror.74 (Page Supp. 1956) (the articles may take this right away); OKLA. STAT. tit.

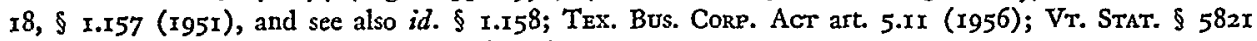
(1947); WASH. Rev. CODE $§ 23.16 .140$ (r95I).

${ }^{8}$ These statutes permit appraisal in such cases: LA. Rev. Stat. $\$$ I2.52 (I950); Mo. Rev. Stat. $\$ 351.090(4)$ (r949) (a limited right); N.Y. Stock CoRP. Law $\$ 38.11$; N.C. GEN. STat. \$\$ 55-ri3, 55-10r(b) (Supp. x955); OHIo Rev. CODE $\$$ I70I.74 (Page Supp. r956) (requires "substantial" prejudice to shares of a class "where the articles do not expressly or by implication provide for or permit such amendment"); OkLA. Stat. tit. $18, \S$ r.157 (195I), and see also id. $\S$ r.I58; PA. STAT. ANN. tit. I5, $\$$ 2852-8 ro (Supp. 1956) (where a pre-emptive right is taken away); WASH. REv. CoDE $\$ 23.16 .140$ (195I); Md. ANN. Code art. 23, $\$ 69$ (a)(3) (195I), as amended by Md. Laws 1933, c. 405, referring to art. 23, $\$$ io (for encroachment on shareholders' contract rights when the charter does not reserve the right to make the particular amendment). 
mediately clear. If the share's dividend rate, redemption price, par value, dissolution preference, and a host of other preferences may be changed to the disadvantage of the shareholder, the policy of giving him an appraisal right would seem to be highly reasonable. His contract, changeable as a chameleon, has none of the protection which changeable hues afford this little reptile. On the other hand, such changes in his contract are normally not made unless economic conditions demand them; and, if the stated majority of his class votes in favor of them, together with the stated majority of other classes of shares outstanding, it is arguable that economic necessity overbalances the personal right which appraisal provisions would create. His plight certainly is no worse than that of his fellow shareowners who have voted to give themselves something less than that to which their contract entitled them.

Important also in a determination of whether appraisal rights should be narrowly confined or broadly granted are the equitable limitations which bind controlling owners in the exercise of their powers. Thus, when voting power is sufficient to authorize a fundamental change, it must be used with fairness and without favoritism to any shareholder or shareholding group. Controlling shareholders have a legal duty to procure a fair price in a sale of corporate assets, fair terms upon a merger or consolidation, and equal treatment upon a dissolution when they so legislate. ${ }^{9}$ When those in control act, they have a fiduciary obligation to the remainder to act with fairness, a sort of civil due process in corporate government. ${ }^{10}$ And prompt attack may be the means of restraining majority action falling short of these standards.

It necessarily follows, therefore, that when a stated majority acts in areas where the dissenting shareholder may claim an appraisal right, the dissenter must be given a fair opportunity to participate with the majority in a plan which has been conceived in the light of these principles of equitable limitation. Otherwise, he will be forced to seek appraisal, for he has no real choice.11 If a stated majority has used one authorized device to reach a result authorized by another device, perhaps to avoid the appraisal right-as, for example, where the sale-of-assets provision is used to effect a merger or consolidation; or where the dissolution provision is used not for going out of business, but to oust some of the owners so that the remainder may carry on under a new corporate or other business organization flag-another

${ }^{\circ}$ Outwater v. Public Service Corp. of New Jersey, I03 N.J.Eq. 461, 143 Atl. 729 (Ch. 1928), af'd, 104 N.J.Eq. 490, I46 Atl. 916 (Ct. Err. \& App. 1929). See dictum in Allied Chemical \& Dye Corp. v. Steel \& Tube Co. of America, I4 Del. Ch. I, x8, I20 Atl. 486 (Ch. 1923); Allaun v. Consolidated Oil Co., I6 Del. Ch. 318, I47 Atl. 257 (Ch. 1929). Cf. Wall v. Anaconda Copper Mining Co., 216 Fed. $242,243,246$ (D. Mont. I9 4 ). An illuminating recent case on the valuation of assets upon a sale is Baron v. Pressed Metals of America, Inc., II7 A.2d 357 (Del. Ch. I955), motion for reargument demed, I 8 A.2d 360 (Del.Ch. I955), aff'd, I23 A.2d 848 (Del. Sup. Ct. 1956).

10 "Unless the majority in such case are to be regarded as owing a duty to the minority such as is owed by the directors to all, then the minority are in a situation that exposes them to the grossest frauds and subjects them to most outrageous wrongs." Allied Chemical \& Dye Corp. v. Stcel \& Tube Co. of America, I4 Del.Ch. I, I2-13, I20 Atl. 486, 49x (Ch. 1923).

${ }^{11}$ See Colgate v. U.S. Leather Co., 73 N.J.Eq. 72, 98, 67 Atl. 657, 668 (Ch. 1907). The recent North Carolina statute, however, specifically recognizes the possibility of other rights "in law or equity." N.C. GEN. STAT. $\$ 55-I_{3}$ (b) (Supp. 1955), and see infra note 48 . 
simple rule comes into play: One authorized device may not be used to accomplish a result within the purview of another authorized device or to reach a result not yet sanctioned. ${ }^{12}$ Thus, the common law has worked out some reasonable limitations upon the exercise of power in corporate government as it relates to the owners of the corporation, limitations to which legislatures should be sensitive when requested to simplify majority action by relegating dissenters to an appraisal of their shares when it appears that the statutorily-prescribed majority has approved or consented to the change. ${ }^{13}$ While reasonable freedom of action by the majority owners is desirable, dictatorship is just around the bend when minorities are left but one choice, and that one through the appraisal route. It would, indeed, be unfortunate if the legislative cure for minority obstruction should be the means of obliterating a century of common law which has been striving to put honorable business practices into corporate profit-making and sharing.

\footnotetext{
${ }^{12}$ Thus, in Ervin v. Oregon Ry. \& Navigation Co., 27 Fed. 625 (S.D.N.Y. I886), the court condemned the use of a dissolution provision to effect a consolidation and virtual reorganization, without giving minority interests the opportunity to participate; in the process, the corporate assets had actually been sold by the majority to themselves for an inadequate price. Similarly, in Meyerhoff v. Bankers' Securities, Inc., I05 N.J.Eq. 76, I47 Atl. 105 (Ch. 1929), where a sale-of-all-assets section had been projected as a means to be used to bring about a dissolution, the court required compliance with the dissolution section. And in Finch v. Warrior Cement Corp., I6 Del.Ch. 44, I4I Atl. 54 (Ch. I928), where the sale-of-assets section was to be used to accomplish a reorganization and stock was to be taken as the purchase price and distributed to the shareholders rather than to the selling company, the court held that if the majority insisted upon a sale as the method of reorganizing the company's affairs, the minority was entitled to insist that it be a sale and not a merger, which legally it would be. So, too, in William B. Riker \& Sons Co. v. United Drug Co., 79 N.J.Eq. 580, 82 Atl. 930 (Ct. Err. \& App. I912), where the dissolution section had been used to effect a consolidation with a foreign, corporation, the court held that there must be a bona fide dissolution intended to end the corporate life; otherwise, there would be a "fraud upon the statute." And in accord is Doe Run Lead Co. v. Maynard, 283 Mo. 646, 223 S.W. 600 (1920). And, again, in Theis v. Spokane Falls Gas Light Co., 34 Wash. 23, $74 \mathrm{Pac} 1004$ (1904), the court balked the use of the dissolution device to oust an obstreperous shareholder who would not sell his shares and the formation of a new company by the majority to take over the operation. For a more thorough treatment, see Lattin, Equitable Limitations on Statutory or Charter Powvers. Given to Majority Stockholders, 30 Mrch. L. Rev. 645 (1932). An interesting provision which the draftsmen must have designed to accomplish one result through the use of a device calling for a smaller proportionate shareholder vote is contained in N.C. GEN. STAT. $\$$ 55-I08(b) (Supp. I955). This is a very wise provision.

${ }^{13}$ But see Porter v. C. O. Porter Mach. Co., 336 Mich. 437, 58 N.W.2d 135 (1953), noted in 52 Mich. L. Rev. 451 (1954), where there was a sale of all the assets for shares in a corporation organized for the purpose of buying the assets in order to continue the life of the corporation another thirty years. The constitution required a shareholders' vote to renew the corporate life for another thirty years, and the necessary two-thirds vote could not be obtained; but a sufficient number could agree on a sale of assets, which required a majority vote. See also CAI. CoRp. CODE $\$ 4123$, which makes the appraisal right the sole remedy, but which permits the shareholder to "test whether the number of shares required by statute to authorize or approve the merger or consolidation have been voted in favor thercof by persons legally entitled to vote them . . ."; Beechwood Securities Corp. v. Associated Oil Co., I04 F.2d 537 (9th Cir. 1939), where a fraudulently unfair exchange of shares was authorized in a merger and the minority was told its only remedy was by appraisal under the California statute; $\mathrm{PA}_{\mathrm{A}}$ Stat. ANN. tit. I5, $\$ 2852-810,2852-908$ (subd. $C$ of each section reading: "The rights and remedies, at law and in equity, of any shareholder who desires to object to or to dissent from any such amendment shall be limited to those prescribed under this section, and such rights and remedies under this section shall be exclusive."); Bloch v. Baldwin Locomotive Works, 75 D. \& C. 24,38 Del. Co. II7 (1950). There seems to be no particular enthusiasm for this type of legislation elsewhere, which, to the present writer, at least, indicates that the fusion of law and morals in this area is likely to remain.
} 
The proportion of shareholders that may vote fundamental changes, where the articles contain no governing provisions in the matter, varies considerably from state to state. While Montana permits shareholders representing "at least one-half" of the outstanding capital stock of record entitled to vote at the meeting to authorize a sale of the corporate assets, ${ }^{14}$ other jurisdictions require not less than a majority, and most of them require at least a two-thirds vote-Alabama, in fact, requiring an affirmative vote of two-thirds of the directors and holders of four-fifths "in value" of the capital stock. ${ }^{15}$ Thus, the variation is from fifty to eighty per cent, with a preponderance at $66 \% 3$ per cent, but with a respectable number permitting a bare majority to control. The difficulty does not end with the fraction required, however, for the statutes vary considerably, too, on the question of which shareholders may vote-only those who have voting shares ${ }^{16}$ or shares entitled to vote in case of a sale of the assets, ${ }^{17}$ or all shareholders, whether or not they have voting rights in other cases. ${ }^{18}$ Where there are classes of shares, the usual provision requires an affirmative proportionate vote of each class; but this provision is valueless to holders of a class of shares with no voting rights where the statute provides for a vote solely by holders of shares with voting rights or with voting rights only in case of a sale of assets. ${ }^{19}$ And where there is no provision for a vote by classes of shares, the proportionate vote required may be carried by the common shareholders' votes, even where all shares have voting rights and a considerable portion of a class votes against the resolution. In the case of a sale of assets, this is perhaps not too troublesome a problem, although it does offer opportunities of selling out a prosperous

${ }^{24}$ Mont. Rev. Codes Ans. $\$ 15-901$ (1955). Cf. Conn. Gen. Stat. $\$ 5138$ (1949) (requires authorization "by a vote of $3 / 4$ of all its outstanding stock of cach class"); Mo. REv. STAT. $\$ 351.400$ (1949) (requires the affirmative vote of holders of at least three-fourths of the outstanding stock entitled to vote at such meeting); S.D. CoDE $\S 11.0709$ (1939) (requires shareholders representing thrce-fourths of the outstanding stock to authorize a sale or mortgage); W. VA. CoDE ANN. \$3076 (I955) (requires for a sale an affirmative vote of the holders of sixty per cent of the stock issued and outstanding having voting power).

${ }^{25}$ ALA. CODE tit. IO, \$ 9I (1940). Texas, likewise, requires a four-fifths vote of all outstanding shares, whether with or without voting rights. TEx. Bus. CoRp. Acr art. 5.10 (1955).

${ }^{10}$ E.g., DeL. CODE ANN. $\$ 27 x$ (1953) (the "affirmative vote of the holders of the majority of the stock issued and outstanding having voting power"); D.C. CODE ANN. 29-929 (Supp. 1956) (at least two-thirds of the outstanding shares entitled to vote, and if there are two or more classes entitled to vote, each class must have a two-thirds affirmative vote); KAN. GEN. STAT. ANn. \$ 17-3801 (1949) (two-thirds in amount of its outstanding shares of capital stock entitled to vote); Mass. Gen. Laws c. $156, \S 42$ (1932), as amended by Mass. Laws 1943, c. 38 (two-thirds of each class entitled to vote).

${ }^{17}$ E.g., FLA. STAT. $\$ 608.19$ (I955) ("affirmative vote ... of shareholders of record holding at least a majority of stock entitled to vote on such proposal"); GA. CODE ANN. \$22-1870 (Supp. 1955) (similar to the Florida statute); ILL. REv. STAT. c. 32, $\$ 157.72$ (1955) (approval of two-thirds of the outstanding shares entitled to vote at such meeting); N.J. Rev. STAT. \& 14:3-5 (1937) (two-thirds in interest of the holders of each class having voting powers on the proposal).

${ }^{18}$ E.g., Colo. Rev. Stat. ANn. $\$ 3$ I-6-2 (I953) (the affirmative "vote of $\% 3$ of the entire outstanding capital stock of the corporation"); ConN. GEN. STAT. $\S 5138$ (1949) (provides for a sale "when authorized by a vote of $3 / 4$ of all its outstanding stock of each class").

${ }^{10}$ E.g., D.C. Code ANN. $\$ 29-929$ (Supp. 1956); Ill. Rev. Stat. c. 32, 157.72 (1955); MD. ANN. CODE art. 23, $\S 6 \mathrm{I}, 62$ (195I); MAss. GEN. Laws c. 156, $\$ 42$ (1932), as amended by Mass. Laws I943, c. 38 . 
corporation through the vote of a small proportion of the total shares outstanding, even where the sale is for shares in another company or for property other than cash.

A difference also exists in some statutes between the proportion and/or quality of shareholding interest-i.e., whether with or without voting rights-necessary to authorize a sale of assets and that required in case of a merger or consolidation. For example, Alabama requires a four-fifths-in-value-of capital-stock vote to consummate a sale of assets, whereas two-thirds in value of each merging or consolidating company's shares is sufficient to accomplish a merger or consolidation. ${ }^{20}$ On the other hand, California permits a "majority of voting power" to control in a sale of assets and not less than two-thirds of the issue, and outstanding shares, regardless of limitations or restrictions on their voting powers, to authorize a merger or consolidation. ${ }^{21}$ And while the same proportionate vote, namely, three-fourths, is required in either case in Hawaii, only holders of shares with "voting power" have a voice in a sale of assets, although holders of shares outstanding, with or without voting rights, may be heard in the matter of a merger or consolidation. ${ }^{22}$ May there be a difference in underlying policy justifying the different requirements in these statutes? The considerable number of statutes that draw few or no distinctions with respect to either the proportion of votes necessary or the quality of the shareholding interest in these cases, however, apparently reflects a widespread nonrecognition of such possible policy distinctions.

But there are a sufficient number of statutes prescribing different percentages of voting power-sometimes a higher percentage for a sale of assets; sometimes the reverse; sometimes prescribing that only voting shares shall vote in the case of a sale and that all shares, whether carrying a vote or not, may vote in the case of a merger or consolidation-to warrant speculation as to what might have been in the minds of the framers of these several provisions. Is it possible that shareholder rights differ relatively in the case of a sale of all or a large part of the assets of a solvent and possibly highly successful company and in the case of a merger or consolidation? Would the requirement of a larger proportionate vote or consent in one situation

${ }^{20}$ Ala. Code tit. I0, $\$$ 91, 94 (I940). Cf. Conn. Gen. Stat. $\$ \$ 5138,5222$ (1949) (requires a three-fourths vote of the outstanding shares of each class for a sale of assets, but approval of two-thirds of the outstanding shares of each class for a merger or consolidation); MICH. Comp. LAws $\$ \$ 40.57$, 450.54 (Supp. 1956) (requires a majority of the outstanding shares for a sale of assets, but approval of two-thirds of the outstanding shares of each class for a merger or consolidation); Mo. REv. Stat. $\$ \$ 35 \mathrm{r} .400,35 \mathrm{r} .425$ (1949) (requires three-fourths of the outstanding shares entitled to vote "at such meeting" for a sale of assets, but approval of two-thirds of the same shares for a merger or consolidation); N.C. GEN. STAT. $\$ 55-112$ (c) (3), 55-108(b) (Supp. 1955) (requires a two-thirds vote of the outstanding shares for a sale of assets, but a majority vote for a merger or consolidation). Other examples could be given.

${ }^{21}$ Car. Corp. Code $\$ \$ 3901,3902,3903,4$ 107. Cf. Mont. Rev. Codes ANn. $\$ \S 15-901,15-902$ (1955) (allows one-half of outstanding shares of record entitled to vote at the meeting to authorize a sale of assets, but requires two-thirds of the stock to authorize a merger or consolidation).

${ }^{22}$ HawaII Rev. Laws $\$ \$ 8343,8363$ (x945). Cf. INd. ANN. Stat. $\$ \$ 25-239,25-23$ I (Supp. 1957) (vote of two-thirds of the outstanding shares entitled to vote in respect thereof for a sale of assets when corporation is meeting its matured obligations, but a majority only of the outstanding shares entitled to vote for a merger or consolidation is required for this major change). Other examples could be given. 
than in the other warrant a conclusion that there are greater dangers to the shareholders inhering in the situation requiring the larger percentage vote? Should the probable dangers be sufficiently evident for rational minds to conclude that the dangers are greater in a merger or consolidation than in a sale of assets, or vice versa?

It seems doubtful that the various approaches which legislatures have adopted to these problems can be explained upon other than a flip-of-the-coin basis. And one is led to believe that there is no sound reason for requiring a different percentage or quality of shareholder interest vote in one case than is required in the other; that both situations have their special potential dangers which warrant approximately equal treatment vote-wise. There may be more ground for controversy, however, concerning the question whether each situation equally warrants giving a right to the dissenting shareholder to be paid the fair value of his shares through the appraisal procedures and how those procedures shall be exercised. These problems have yet to be considered.

First preference with respect to the right of appraisal should, perhaps, be accorded in the situation where amendments may either place ahead of an outstanding stock, whether common or preferred, another class with superior preferences, or alter all kinds of contractual rights, including the elimination of accrued but undeclared dividends on cumulative preferred shares. Yet, less than one-fifth of the states accord an appraisal right to a dissenting shareholder of a class whose shares are thus impaired. ${ }^{23}$ If he cannot find an outside purchaser, he must keep his shares and suffer the damage attributable to the alteration. If economic conditions have justified a change of the terms of his original contract, there is, perhaps, some reason for a policy which, under such circumstances, would sanction this result. Necessity excuses many things. But the statutes do not limit such changes exclusively to those necessary to keep the corporate boat afloat. And the dangers inherent in the many substantial changes specifically permitted in a vast number of fairly recently-enacted statutes give cause for sober pause. The great bulk of these provisions, moreover, requires the board to submit amendments but gives the shareholder no right to do likewise. Hence, if the shareholder feels that dissolution or a sale of all of the assets is a better solution, he has no chance to present his case to the other shareholders.

Approximately twenty states require approval of amendments altering shareholders' rights by a two-thirds vote, with a further provision that if a class of shares is adversely affected, its holders shall have a vote as a class-usually whether they have voting rights in other situations or not-and holders of two-thirds of the shares of the class as well as holders of two-thirds of the total outstanding shares with voting rights must approve the change. Approximately the same number of states permit such changes to be approved by a majority vote, with similar action by holders of a majority of the shares of the classes affected. A few states have no

${ }^{23}$ See note 8 supra. 
provision for a class vote in any case $;^{24}$ a few draw a distinction between the proportion required in the vote of a class affected ${ }^{25}$ and that required in the vote of the other shares; and Rhode Island requires a unanimous vote in some situations, a twothirds vote in others, and a majority vote in others. ${ }^{26}$ Usually, where one or more classes may be affected by the change, the statutes give a vote to the shareholders of such classes, whether or not they have a voting right in other situations. But some of the statutes draw no such distinction and permit only the holders of voting shares to be heard on these important changes. ${ }^{27}$

There is also confusion in the manner of statement in some statutes as to whether the holders of voting shares are intended to be the only ones that may be heard, or whether all shareholders may vote, or whether, in special circumstances, some shareholders not otherwise entitled to vote may do so in the case at hand. But, by and large, the statutes are clear as to who may vote and when. And this is important, for there is enough confusion in the area of fundamental change without more being caused by careless draftsmanship.

Where voluntary dissolution is the fundamental change anticipated, thirty-four states and the District of Columbia require a two-thirds vote, several require not less than a majority vote, one omits any statement on the proportionate vote required, and the remaining six require from-a fifty to eighty per cent vote. ${ }^{28}$ Again, there is no agreement as to which shareholders may vote-whether those with voting rights, those with such rights on a resolution for dissolution, or all, whether with or without voting rights in other matters. A few statutes, but only a few, recognize specifically the case of deadlocked boards and/or shareholders, a situation which in the closely-held corporation can be embarrassing and damaging in a vital sense. It would seem that all corporation statutes should contain some provision for dissolution in such cases, either summarily upon application of a shareholder or upon proof that dissolution is for the best interests of the corporation and its shareholders when they cannot break the deadlock by other means. ${ }^{29}$ There are also a

sh E.g., MoNr. Rev. Codes ANn. $\S 15-203$ (1947) (two-thirds of the shares entitled to vote at such a meeting, but no class vote unless the articles provide for this); S.D. CODE $\$$ Ir.0206 (Supp. 1952).

${ }_{25}$ MaINe Rev. StAT. ANn. c. 53, $\$ 75$ (I954) (requires a majority of the shares entitled to vote, but also a class vote, when the class is affected as described in statute, of eighty per cent of the shares of the class); Kr. REv. STAT. $\$ 271.445$ (1953) (requires a majority of the shares entitled to vote, with the addition of a two-thirds vote of the class adversely affected); Mo. Rev. STAT. $\$ 35$ r.090 (r949) (a complicated statute, but a majority of the shares entitled to vote, plus seventy-five per cent of the shares of the class adversely affected, and in some cases, a unanimous vote of the shares of a class is required).

${ }^{23}$ R.I. GEN. LAws ANN. c. xi6, $\$ 50$ (1938).

${ }^{27}$ N.H. REv. Stat. ANN. $\$ \$ 294.40,294.41$, as amended by N.H. Laws 1955, c. 19; N.M. Stat. AnN. \$ 5x-2-20 (1953); N.Y. STOCK CoRp. LAw $\$ 37$.

${ }^{28}$ Florida, Kentucky, Massachusetts, New Hampshire, Oregon, Pennsylvania, and South Carolina provide for a majority or, in some cases, "not less than majority" vote. California permits a fifty per cent vote, and Rhode Island prescribes fifty per cent "or more." West Virginia requires a sixty per cent, Connecticut a three-fourths, and Alabama and Texas a four-fifths vote. No proportion is stated in the Vermont statute. All have to be watched to see whether the vote is limited to voting shares or to shares entitled to vote on a liquidation resolution.

${ }^{20}$ See N.Y. GEN. CORP. LAW $\S$ I03; CAX. Corp. CODE $\$ 4650$ (one half of directors or holders of one third of outstanding shares are allowed to petition for dissolution); N.C. GEN. STAT. \$ 55-125 (I) and (2) (Supp. 1955). There are other excellent provisions in this well-framed North Carolina section. 
number of situations where dissolution should be left to the board of directors, thus saving time and expense in dissolving a corporation in special situations, such as insolvency, bankruptcy, end of term of life, etc.; and a fair number of statutes today make such exceptions from those requiring a shareholder's vote. ${ }^{30}$ And, as is usual in other fundamental-change situations, there is, as a rule, a provision for dissolution upon the written consent of all the shareholders.

Recent appraisal provisions have generally been prolix in statement, spelling out to the last detail the procedures that must be followed by dissenters to secure payment for their shares. Little attempt, apparently, has been made to simplify these statutory provisions so that the layman might have some conception of their full import. Some things should be stated, and these include the events giving rise to appraisal rights; a description of the shares or classes entitled to appraisal; the kind of dissent to, or objection to, or vote against the proposed change that must precede assertion of the right of appraisal; the machinery to be employed in making the appraisal when the shareholder and his corporation do not agree on value; and the point at which some value becomes final, with no further contest possible by the corporation or the dissenting shareholder. There should also be clear indication of when the dissenter loses his status as a shareholder, so that cash and share dividends or pre-emptive and other rights to which he might otherwise have become entitled thereafter may not accrue to him or to his assignee or devisee; or whether he retains all or a part of his rights as a shareholder from the time of his dissent and demand until the actual payment or tender of payment and surrender of his shares. ${ }^{31}$ If the dissenter loses his shareholder status when he demands that he be paid the fair value of his shares, provision should be made for the highest legal rate of interest from that date to the date of actual payment; and if the anticipated transaction does not materialize, but is abandoned, his rights as a shareholder should be secured in such manner that, except for the voting right in the interim, he will receive everything that other shareholders in the majority group did. It should be clear, too, whether his corporation is to pay him in the case of a merger or consolidation or a sale of assets for shares in the buying corporation, or whether he is to be paid by the surviving corporation in the merger, the new corporation arising from the consolidation, or the corporation purchasing the assets, as the case may be. It should be just as clear whether the payment may be made out of any funds or only those usually legally applicable when shares are purchased by the corporation under other circumstances. There should be, as well, a point at which the corporation must elect whether it will abandon the project or consummate it and undertake the paying off of the dissenters. And to complete the remedy, there should be provision for the payment of the costs of appraisal.

There is still merit in the brevity of the statement of the provisions contained in the Model Business Corporation Act of 1928,32 originally denominated the Uni-

${ }^{30} \mathrm{See}$, for good recent statutory example, N.C. GeN. STAT. $\S 55-1 \times 6$ (Supp. 1955).

${ }^{32}$ See Fein v. Lanston Monotype Machine Co., 196 Va. 753, 85 S.E.2d 353 (1955).

${ }^{32} 9$ U.L.A. II5 (1957). 
form Business Corporation Act. In three rather short paragraphs, section forty-two of this Act was able to state simply, without embellishment or tautology, the essentials of dissent, demand, effect of failure to agree, appraisal, and finality of appraisal, with a protective provision preventing payment if the debts and liabilities, not including that of capital stock, exceed the value of the corporate assets. Section forty-eight added in one short paragraph the right of appraisal in the case of a merger or consolidation, making the liability to pay for the dissenters' shares "also a liability of the surviving or new corporation, as the case may be." These provisions were drafted at a time when little was known of the finer points that needed solution, but legislators might well study them as fine examples of the simplicity and clarity of statement which all legislation should possess.

The Michigan statute, which became effective in I93I and which was one of the early statutes with fairly adequate provisions concerning dissenting shareholders, ${ }^{33}$ was fashioned after the I928 Model Act and the Ohio Act of $1927 .^{\mathbf{3 4}}$ Not as brief, but still short when compared with several of the more recent statutes, it exhibits, in large part, the clarity necessary to make it workable, although one may not agree entirely with some of its features. For example, why should it be necessary for a shareholder to vote against a proposal as a condition of his right to seek appraisal? If a shareholder has not voted for a proposal, why should he not be allowed to demand an appraisal within the specified period of time? Again, why should a shareholder's right to contest the fairness-or even the downright fraud-of a sale, lease, or exchange of corporate property, or the terms of a merger or consolidation, or any other transaction where appraisal rights are given be cut off by making appraisal "his exclusive remedy?"35

When the corporation and the shareholder cannot agree, the I928 Model Act makes final the appraisers' finding of the "value of the shares at the time such corporate action was authorized," which amount, if not paid within thirty days, may be recovered by the shareholder in an action against the corporation. ${ }^{36}$ The Michigan statute is not quite as summary, for it requires the court, rather than the parties, to select the appraisers and further requires court confirmation of the appraisers' report before it becomes "final and conclusive," no appeal being permitted. ${ }^{37}$ The Michigan statute also provides for the exclusion of any appreciation or depreciation in the "fair cash value" of the shares owing to the corporate action as of the day prior to the day

${ }^{53}$ Mtch. CoMrp. LAws $\$ \hat{\S} 450.44$ (I948), 450.54 (Supp. 1956).

${ }^{36}$ II2 Ohio Laws $\$ \$ 8623-1-138$ ( 1927 ).

${ }^{35}$ Note 33 stupra. The California statute also makes appraisal a dissenter's sole remedy. Cal. Corp. Code $\$$ 4123. See also Porter v. C. O. Porter Machinery Co., 336 Mich. 437, 456, 58 N.W.2d r35, I37 (1953); Beechwood Securities Corp. Inc. v. Associated Oil Co., ro4 F.2d 537 (gth Cir. 1939) (interpreting the California statute where fraud was claimed). But while the Michigan statute purports to make the appraisal remedy exclusive, see Horace L. WiLgus and BurritT HAMmtiton, Michigan CorpoRation LaW 323 (1932) and the dictum in the Porter case, supra at 456,58 N.W.2d at 137. Cf. Pennsylvania statute, stipra note 13; Beloff v. Consolidated Edison Co. of N.Y., 300 N.Y. 1x, 87 N.E.2d 56x (r949).

${ }_{\text {so }}$ Model Business Corporation Act of $1928 \S 42$.

${ }^{37}$ Note 33 supra. 
"such action was authorized by the shareholders," statutes, whereas the I928 Model Act contains no reference to this matter. The Michigan statute further requires the shareholder to surrender his share certificates to the corporation when he makes his demand for payment, in contrast with those few present-day statutes that require him to present his shares to have stamped upon them the fact that they are dissenting shares. ${ }^{39}$

Concerning the culmination of the appraisal procedure, the Michigan statute provides that the final act of payment for dissenting holders' shares shall only be made when the value of the corporate assets after payment would exceed ixo per cent of the aggregate amount of the corporation's debts and liabilities, excluding capital stock, "and if such excess shall be at least equal to the awarded and/or agreed fair cash value of the shares of shareholders demanding payment." ${ }^{\prime 0}$ Does not this quoted clause mean that if the corporation has assets equal to IIo per cent of its liabilities, etc., and $\$ 1,000,000$ more, then if the appraisal value of the dissenting holders' shares amounts to $\$ 1,000,100$, nothing can be paid to them and the corporation may go ahead with its sale, lease or exchange, without reference to their appraisal rights? This provision, however, apparently has no application in the case of a merger or consolidation, where payment must be made by the "resulting" corporation. ${ }^{41}$

The Michigan statute also contains provisions disentitling the dissenting holder who demands payment to the rights arising from his ownership of shares, unless the corporation abandons its plans or he withdraws his demand with the board's consent. Interest is mentioned in neither this statute nor in the 1928 Model Act, although it should be pertinent in any case where the shareholder's rights are suspended or payment is to be made on a valuation determined as of a date prior to or as of the date of the corporate action giving the appraisal right. The corporation has the use of the money during the ensuing interim period, and corporate earnings during that period are not to be considered in fixing the value. If cash or stock dividends are declared or pre-emptive rights acquired during the period, however, and the statute does not mention these or the suspension of shareholder rights after demand for payment, it seems clear that the shareholder would be entitled to these benefits.

Having examined a model act of early vintage and a state statute of the same period which has sustained but minor change since becoming effective, it should be interesting to compare the very recent American Bar Association's Model Business Corporation Act in its revised edition of 1953 with one of the most modern of the

${ }^{38}$ Ibid.

${ }^{30}$ Ibid. But of. OHro Rev. Code ANN. $\$ 1701.85$ (A) (Page Supp. 1956) (if the corporation requests it, the certificates must be submitted for the purpose of indorsing thereon "a legend to the effect that demand for the fair cash value of such shares has been made"); CAL. CoRp. CoDE $\$ 4302$ (sharcs must be stamped that they are dissenting shares, with a provision that upon subsequent transfer on the books, the new certificates shall bear a like statement, together with the name of the original dissenting holder of the shares).

${ }^{10}$ Note 33 supra.

${ }^{11}$ Ibid. 
recent state corporation statutes, that of North Carolina. The 1953 Model Act was prepared by a committee of the American Bar Association over a period of years, an initial draft having been published in I946, following a preliminary report published in 1943. Simplicity and clarity of expression as well as style were sought by the draftsmen, and, having satisfied, in a large measure, its draftsmen's objectives, the 1953 Model Act should be instructive as an example of what can be done with the English language if men devoted to a search for "plain and precise" language set out to do a job. Furthermore, "a great deal of consideration has been given to the rights of shareholders," the draftsmen admitting that such rights have almost ceased to exist in some states. ${ }^{42}$

There are two sections in the 1953 Model Act which accord appraisal rights to dissenting shareholders: ( $\mathrm{I}$ ) section seventy-one, which pertains to mergers and consolidations; and (2) section seventy-four, which applies in the case of a sale or exchange of all or substantially all of the assets of a corporation in other than the usual and regular course of business. Unfortunately, however, no appraisal rights are granted in the case of amendments which seriously impair the share-contract rights, a situation in which shareholders most certainly deserve protection. Although a host of major changes may be made in his contract rights, the only protection the shareholder can assert is the right to a class vote, whether or not his shares have that right on other occasions, and the requirement that there be at least a twothirds vote of his class and a similar proportion of other classses affected and of the remaining shares in favor of the change.

The new North Carolina statute, which became effective July I, I957, goes much farther, however, in the matter of protecting dissenting shareholders. ${ }^{43}$ Voting rights are given in all cases where appraisal is permitted, as in the 1953 Model Act, with class-voting rights being preserved where amendments adversely affect the sharecontract, and appraisal rights being granted to objecting shares with preferences as to dividends or liquidation in specifically stated situations where their holders' interests will be prejudiced. ${ }^{44}$ There is also a much-needed provision to protect dissenting holders against a recapitalization which creates a new class of shares, or other securities, with priorities in rights over existing preferred shares upon which there are accrued dividends or dividend credits, even though the preferred shareholder is offered the opportunity of turning in his own shares for the new ones. ${ }^{45}$ This provision, no doubt, is intended to obviate the effect of some drastic decisions which permitted accrued but undeclared dividends effectively to be wiped out by this

\footnotetext{
"See Mrr. Ray Garrett's preface to the 1950 revision. Committeg on Corporate Laws, American Bar Associntion, Model Business Corporation Act iv-x (1953). The history and purposes of the Act are here set out. Some slight revisions, together with accompanying optional provisions, appear in a nine-page pamphlet, published in r955. Id., Revisions and Optronal Sections (I955).

${ }^{\star 3}$ N.C. GEN. STAT. $\$ 55-113$ (Supp. $\times 955$ ). Fundamental changes start with $\S 55-99$ and are stated in terse, short subsections wherever possible, thus making for clarity and easy understanding.

"Id. $\$$ 55-ror.

${ }^{4} I d . \$ \$ 55-\operatorname{IO}(\mathrm{b})(2), 55-102$. These two provisions are directed at the same evil, but $\S 55-102$ is concerned with a situation not requiring an amendment to the articles.
} 
method, where it was impossible under the then existing law to destroy such rights by a "direct" amendment. ${ }^{46}$ And, of course, under the majority decisions which permitted this rough treatment, no appraisal right existed without the aid of a statute. Moreover, upon dissolution, where liquidation is effected by a transfer of assets in kind "to the shareholders collectively as co-owners," the North Carolina statute also gives an appraisal right. ${ }^{47}$ Merger and consolidation, too, with domestic or foreign corporations gives a dissenting shareholder the right to be paid the fair value of his shares, "in addition to any other right he may have in law or equity," thus specifically assuring him that appraisal is not his only remedy. ${ }^{48} \mathrm{He}$ can, thus, enjoin an unfair or fraudulent merger or consolidation, a remedy which neither the California nor the Michigan statutes seems to countenance. ${ }^{49}$ And this statute affords appraisal remedies as well to one who dissents and demands payment in the statutorily-prescribed manner upon a sale of assets for shares of another corporation. ${ }^{50}$

A salient feature of the North Carolina statute which should encourage honest action by the majority junior shareholders when major changes are contemplated is a provision which dictates that "the fair value of any shares entitled to preference on liquidation shall in no event be found to be less than two-thirds of the amount of the preference to which said shares would have been entitled on a voluntary liquidation on the date herein" if junior shares retain a participation in the corporation without payment therefor, and in case of payment for participation, if the value of the participation exceeds the payment for it. ${ }^{51}$ There will, no doubt, be practical difficulties in ascertaining the value of a particular participation, but the problem is no more difficult than that which confronts appraisers in determining the "value," "fair value," "fair market value," or "fair cash value" of dissenting shares, for very few statutes give any indication of tests of value to be employed in making appraisals.

${ }^{10}$ Sec, e.g., Barrett v. Denver Tramway Corp., 53 F. Supp. 198 (D.Del. 1943), aff'd, 146 F.2d yor (3d Cir. 1944); Johnson v. Lamprecht, 133 Ohio St. 567, 15 N.E.2d 127 (1938); Shanik v. White Sewing Machine Corp., 25 Del. Ch. 371, I9 A.2d 831 (Sup. Ct. r941). Contra, Patterson v. Durham Hosiery Mills, 214 N.C. 806, 200 S.E. 906 (1939). For other cases, see HenRY W. Ballantine, Norman D. Lattin, and Richard W. Jennings, Cases and Materials on Corporations 988 n. 2 (2d ed. 1953).

${ }^{4}$ N.C. Gen. STAT. $\$ 55-1$ I9(b) (Supp. I955).

48 "In addition to any other right he may have in law or equity, a sharcholder giving such notice shall be entitled, if and when the amendment, dissolution, merger, consolidation or sale of assets for shares is effected, to be paid by the corporation the fair value of his shares, as of the day prior to the date on which the vote was taken, subject only to the surrender by him of the certificate representing his shares." Id. $\$ 55-\mathrm{Ir}_{3}$ (b). This section gives dissenters in North Carolina corporations the same rights whether the merger or consolidation be wholly between domestic corporations, id. $\$ 55-108$, or between domestic and foreign corporations, id. \$ $55-\mathrm{IIr}$, and regardless of the domiciliary state of the merging corporation. See id. $\$ 55-\operatorname{IxI}(\mathrm{c})(\mathrm{r})$ and (2).

${ }^{10}$ See notes 33 and 35 supra, particularly the Michigan case, which suggests that a fraudulent deal might demand different treatment.

${ }_{50}$ N.C. GEN. STAT. $\$ 55-\operatorname{II}_{2}$ (c)(2), II3(b), II3(I) (Supp. 1955), the last section defining the meaning of "sale of assets for shares."

${ }^{51}$ Id. $\$ 55-113(\mathrm{c})$. 
Another fine feature of the North Carolina statute is the requirement that in appropriate situations, the corporation's notice to its shareholders contain a statement that dissenting shareholders are entitled to appraisal rights upon compliance with section 55-II3, together with a specific statement of the twenty-day-notice period during which demand for payment for the fair value of the objecting shares may be made. ${ }^{52}$ Many shareholders are unaware of such rights, and this notice should give them the opportunity to investigate and make a timely demand for payment if they wish it. The provision found in many statutes requiring the dissenting holder who desires payment for his shares to state what he considers to be their value ${ }^{53}$ is believed to be of little practical use, and the fact that the North Carolina statute omits this indicates legislative concurrence in the futility of such provisions, based on the experience of other states which have enacted them. There is more sense to a provision requiring the corporation to state what it considers to be the fair value of its dissenting shares and, if appraisal becomes necessary, owing to disagreement concerning their value, to require the corporation to pay all costs of appraisal, plus reasonable attorney's fees of the dissenter, if the appraisers' valuation is higher than that of the corporation and there is judicial affirmation of this valuation. The corporation, after all, has the means of ascertaining the value of its. shares, whereas the shareholder is hard put to find out more than the market value, if indeed, there is one.

The appraisal machinery provided by the North Carolina statute is fairly similar to that found in many other statutes. The appraisal value date is "the day prior to the date on which the vote was taken," and there is no provision for considering appreciation or depreciation resulting from the proposal acted upon which gave rise to the appraisal right. ${ }^{54}$ Since there is little chance of determining the amount of appreciation or depreciation attributable to the particular corporate action, the omission is a wise one. Furthermore, if the philosophy behind the payment for dissenters' shares is that the dissenters have some right to continue as owners, they should be given an owners' redress, rather than that which they would have received had there been a dissolution, with a paying of creditors and a division of the remaining assets among shareholders. Of course, under this theory, they take their chances. that a depreciation as well as an appreciation may result from the corporate fundamental change.

Appraisal provisions in the North Carolina statute which deserve special praise are (I) the right of all shareholders having appraisal rights to vote, together with

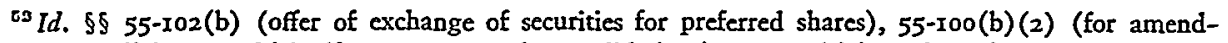
ments generally), 55-108(a) (for mergers and consolidations), $55-\operatorname{Ir}(\mathrm{c})(2)$ (for sales, leases, and exchanges).

${ }^{t 8}$ See, e.g., Orra Rev. Code Ann. $\$$ I70r.85(A) (Page Supp. I956).

${ }^{5}$ N.C. Gen. Stat. $\$ 55-113(b)$, (c) (Supp. 1955) (subsection (c) concerns a special case). Provisions which are similarly aimed at eliminating appreciation and depreciation so caused are common. But see Ono Rev. Code ANN. $\$$ r70r.85 (C) (Page Supp. 1956), which contains an unusual definition of "fair cash value." This provision was inserted in the Ohio statute because the committee framing it was dissatisfied with the court's interpretation of "fair cash value" as "intrinsic value" in Roessler $v_{-}$ Sccurity Savings \& Loan Co., 147 Ohio St. 480, 72 N.E.2d 259 (1947). 
their right to have notice of what their appraisal rights are and notice of the time within which they must exercise these rights; (2) the specific retention by the shareholders of all other legal and equitable remedies, thus assuring a means to attack unfair or fraudulent action, and not solely a right to appraisal; (3) a fair coverage of the several situations which, as a matter of policy, require appraisal remedies, especially share-contract changes of a basic sort, whether by charter amendments compulsory in effect or by "voluntary" exchanges by other shareholders for new securities with priorities over the old shares; and (4) a simplicity of statement and of paragraphing and subparagraphing which makes the statute an easy one to follow and to understand.

\section{ConcLusion}

The recent statutory appraisal provisions show much improvement over those of approximately a quarter of a century ago. ${ }^{55}$ In most of the recent statutes, specific provision is made for such problems as when a shareholder's rights as shareholder cease, whether interest is to be paid on the shares appraised and during what interval, what shareholders may vote and whether by classes or not, and other important matters. There is still a need for a simpler and shorter statement in appraisal statutes, and one wonders, after appraisers have presented their figures to a trial court and that court has confirmed their determination or made a different one, whether an appeal to a higher court is justified. If there is justification, it is only by virtue of the fact that there is little agreement as to what elements must be considered in arriving at a conclusion of what constitutes fair value-or whatever the statute requires. And there is about as much confusion today over this important question as there was a quarter of a century ago. ${ }^{56}$ If appraisal experts can find one or several tests that should be used in such cases, it might be well to suggest that they be placed as guides in the statutes, especially where a more or less summary method of determining value is provided.

${ }^{55}$ The writer had occasion to review such statutes at that time in an article, Lattin, Remedies of Dissenting Stockholders Under Appraisal Statutes, 45 Harv. L. Rev, 233 (1931), and was critical of the statutes which made appraisal a sole remedy in a later article, Lattin, $A$ Reappraisal of Appraisal Statutes, $38 \mathrm{MrCH}$. L. REv. Ix65 (1940).

${ }^{56}$ On the valuation problems, see Application of Behrens, 6r N.Y.S.2d 179 (Sup. Ct. 1946), aff'd, 271 App. Div. 1007, 69 N.Y.S.2d 910 (xst Dep't 1947); In re General Realty \& Utilities Corp., 29 Del. Ch. 480, 52 A.2d 6 (Ch. 1947); Chicago Corp. v. Munds, 20 Del. Ch. 142, 172 Atl. 452 (Ch. 1934); Roessler v. Security Savings \& Loan Co., 147 Ohio St. 480,72 N.E.2d 259 (1947), the effect of which has been cured by Owo Rev. Code Ann. $\$$ r70r.85(C) (Page Supp. 1956). Sce supra note 54. The very recent case of Phelps v. Watson-Stillman Co., 293 S.W.2d 429 (Mo. 1956) discusses the leading cases on valuation; and see also the materials in Ballantine, Lattin, and Jennings, op. cit. supra note 46 , at $1029 \mathrm{n}$. I. 